\title{
POSTAWY MIESZKAŃCÓW WSCHODNICH POWIATÓW DYSTRYKTU WARSZAWSKIEGO RATUJĄCYCH POLSKIE DZIECI - BYŁYCH WIĘŹNIÓW NIEMIECKIEGO OBOZU PRZEJŚCIOWEGO W ZAMOŚCIU W LATACH 1942-19431
}

\section{Beata Kozaczyńska}

Dib http://orcid.org/0000-0002-1653-3472

Uniwersytet Przyrodniczo-Humanistyczny w Siedlcach

\author{
ABSTRACT \\ ATTITUDES OF INHABITANTS OF THE EASTERN COUNTIES \\ OF THE WARSAW DISTRICT WHO SAVED CHILD PRISONERS \\ OF THE GERMAN TRANSIT CAMP IN ZAMOŚĆ IN 1942-1943
}

In December 1942 and in the following two winter months of 1943 during the race selection at transit camp in Zamość (UWZ-Lager Zamosc), Germans deported about 3,500 Polish children, who qualified as "racially worthless" from the camp. Most of them were separated from their parents. After a stay of several days or several weeks at the camp, having been crammed into unheated freight carriages, they arrived in six "death transports" to three poviats: Garwolin, Siedlce and Mińsk Mazowiecki, located in the eastern part of the Warsaw district. The article presents the attitudes of Poles rushing to save the children, disregarding the difficulties that occurred at that time in the face of the prolonged war and German terror. Both the inhabitants of the area known by surnames and those who are now nameless, joined the rescue operation. Their determination, commitment, and sacrifice during the relief operation that lasted for many months under the occupation up until the end of the war, deserve emphasis. Undoubtedly, it was a show of huge selflessness of people of goodwill to save the lives of innocent and defenceless Polish children from the Zamość region.

Keywords: displacement, saving Polish children, German occupation, Zamojszczyzna region.

Słowa kluczowe: wysiedlenie, ratowanie polskich dzieci, okupacja niemiecka, Zamojszczyzna.

${ }^{1}$ Praca powstała w wyniku realizacji projektu badawczego o $\mathrm{nr}$ 2017/25/B/HS3/01085, finansowanego ze środków Narodowego Centrum Nauki w Krakowie. 
Dramat na wpół żywych, zmarzniętych i głodnych polskich dzieci wywożonych z Zamojszczyzny przez Niemców zimą 1942/1943 roku w czasie ostrych mrozów w nieogrzewanych wagonach bydlęcych wstrząsnął Polakami w wielu rejonach okupowanych ziem polskich. W niektórych miastach w tak zwanym Kraju Warty, na przykład Łodzi i Poznaniu, udało się ludności polskiej zabrać część dzieci ze stacji wprost z transportów ${ }^{2}$. W Łodzi i okolicy, wskutek ogromnego poruszenia wśród Polaków, Niemcy zastosowali represje, zaniepokojeni siłą i zgodnością nastrojów polskich. Wszędzie gdzie tylko było to możliwe starano się dzieci wykupić, a nawet wykraść z wagonów (np. w Kutnie czy Warszawie) ${ }^{3}$. W marcu 1943 roku konspiracyjny „Biuletyn Informacyjny” informował o wzorowej postawie polskiego społeczeństwa w całym okupowanym kraju wobec dzieci wywożonych przez okupanta niemieckiego z Zamojszczyzny ${ }^{4}$.

O ogromnym dramacie polskich dzieci z Zamojszczyzny i ich rodzin zadecydował Generalny Plan Wschodni, zakładający germanizację i kolonizację Wschodniej Europy w perspektywie 25-30 lat po zwycięskim zakończeniu II wojny światowej przez Niemców ${ }^{5}$. Próba jego realizacji w czterech powiatach: zamojskim, hrubieszowskim, biłgorajskim i tomaszowskim, określanych Zamojszczyzną, zakończyła się wysiedleniem i wywózką mieszkańców tego terenu między innymi do obozów koncentracyjnych: KL Auschwitz i KL Lublin, zagłady - Kulmhof (Chełmno nad Nerem) oraz przejściowych w Zamościu, Zwierzyńcu, Budzyniu, Lublinie i Łodzi ${ }^{6}$. Do dziś nieznane są losy tysięcy polskich dzieci wywiezionych z Zamojszczyzny do Rzeszy na zniemczenie?

Zupełnie odmienny los spotkał około 3,5 tys. polskich dzieci - byłych więźniów niemieckiego obozu przejściowego w Zamościu (UWZ-Lager Zamosc) ${ }^{8}$ - deporto-

2 Wysiedlone dzieci na Ziemiach Zachodnich, ,Walka” 1943, nr 11, s. 6.

3 Jeszcze o dzieciach z Zamojszczyzny, „Agencja Informacyjna »Wieś«” 1943, nr 8, s. 7; Łajdactwo i serce, „Szaniec” 1943, nr 2, s. 4.

${ }^{4}$ Zbrodnia ,zamojska”-trwa, „Biuletyn Informacyjny” 1943, nr 10, s. 7.

${ }^{5}$ Plany okupanta niemieckiego w odniesieniu do ziem polskich wiązały się z wysiedleniem $80-85 \%$ Polaków na Syberię. W III 1941 r. Hitler uznał, że ziemie polskie w obrębie Generalnego Gubernatorstwa zostaną skolonizowane po wojnie, w ciągu 15-20 lat. 20 VII 1941 r. Himmler osobiście zwiedził Lublin i Zamość. W krótkim czasie polecił Odilo Globocnikowi opracowanie planów utworzenia wokół Zamościa tzw. Niemieckiego Okręgu Osiedleńczego. B. Mąci or-Majka, Generalny Plan Wschodni, Kraków 2007, s. 186; C. Madaj czyk, Generalna Gubernia w planach hitlerowskich, Warszawa 1961, s. $114-116$.

${ }^{6}$ H. Kubica, Zagłada w KL Auschwitz Polaków wysiedlonych z Zamojszczyzny w latach 19421943, Oświęcim-Warszawa 2004, s. 19-20, 28-30; J. Ki ełb oń, Wysiedleńcy z Zamojszczyzny w obozie koncentracyjnym na Majdanku 1943, Lublin 2006, s. 9-10; B. Ko za c zyńs ka, Ocalone z transportów Dzieci Zamojszczyzny. Losy dzieci wysiedlonych z Zamojszczyzny do dystryktu warszawskiego 19421945 / Saved from the Transports: The Children of Zamojszczyzna Region, Siedlce 2011, s. 7.

7 Brak dokładnych danych dotyczących liczby polskich dzieci wywiezionych na zniemczenie. Wiadomo, że w VII i VIII 1943 r. skierowano z obozu przejściowego w Lublinie (ul. Krochmalna) do Rzeszy w celach germanizacyjnych 4454 dzieci w wieku poniżej 14 lat. J. W nu k, Losy polskich dzieci w okresie okupacji hitlerowskiej, Warszawa 1980, s. 109; J. Ki ełb oń, Migracje ludności w dystrykcie lubelskim w latach 1939-1944, Lublin 1995, s. 55.

${ }^{8}$ Niemiecki obóz przejściowy w Zamościu (UWZ-Lager Zamosc) był utworzony 18 XI 1942 r. jako centralny obóz przejściowy dla cywilnej ludności polskiej wysiedlanej z Zamojszczyzny. Podlegał on 
wanych na przełomie 1942 i 1943 roku w sześciu „transportach śmierci” do trzech powiatów: garwolińskiego, siedleckiego i mińsko-mazowieckiego, położonych we wschodniej części dystryktu warszawskiego. Niemcy planowali utworzyć w tym dystrykcie (oraz w radomskim) tak zwane wsie rentowe (Rentendörfer), głównie w miejscowościach zamieszkiwanych wcześniej przez ludność żydowską, którą w 1942 roku stamtąd wywieziono i poddano eksterminacji. We wsiach rentowych zamierzano umieszczać osoby wyselekcjonowane w obozie przejściowym w Zamościu: starców (powyżej 60 lat), dzieci do lat 14 oraz niezdolnych do pracy, chorych, kalekich itp. ${ }^{9}$ Od później jesieni 1942 roku do połowy sierpnia 1943 roku kierowano do tegoż obozu wysiedloną cywilną ludność polską z Zamojszczyzny ${ }^{10}$.

Po upływie zaledwie kilkunastu dni od rozpoczęcia masowych wysiedleń na Zamojszczyźnie Niemcy byli zmuszeni opróżnić częściowo obóz przejściowy w Zamościu. Obóz ten mógł wprawdzie pomieścić 10,5 tys. osób ${ }^{11}$, jednak skrajne przepełnienie baraków i panujące w nich tragiczne warunki higieniczne mogły spowodować wybuch epidemii tyfusu ${ }^{12}$. Począwszy od 7 grudnia 1942 roku, stopniowo wywożono z obozu starców oraz dzieci „,bezwartościowe rasowo”, tj. zakwalifikowane podczas selekcji rasowej jako niespełniające kryteriów rasowych i nienadające się na zniemczenie. Do końca lutego 1943 roku skierowano do wspomnianych powiatów dystryktu warszawskiego sześć ,transportów śmierci”, liczących 5321 Polaków wysiedlonych z Zamojszczyzny ${ }^{13}$. Wśród nich znajdowało się około 3,5 tys. dzieci.

zamojskiej filii Centrali Przesiedleńczej w Łodzi (Umwandererzentralstelle Litzmannstadt - Zweigstelle Zamość). Obóz zlikwidowali Niemcy 18 I 1944 r. H. Kaj te l, Hitlerowski obóz przesiedleńczy w Zamościu. UWZ Lager Zamość, Biłgoraj 2003, s. 18; J. Mars załe k, Hitlerowskie ośrodki terroru w Zamościu [w:] Zamość. Z przeszłości twierdzy i miasta, red. A. Koprukowniak, A.A. Witusik, Lublin 1980, s. 347.

${ }^{9}$ W projekcie organizacji Rentendörfer zapisano: „Wybierze się w tym celu odpowiednie, czyste polskie osiedla wiejskie. Nie ma mowy o tworzeniu nowych, względnie opróżnianiu istniejących wsi”". Wysiedleńcy mieli tam otrzymać mieszkania i kawałek gruntu (0,5 ha). Przewidywano też ewentualne zatrudnienie tych osób w rolnictwie lub u rzemieślników. Archiwum Instytutu Pamięci Narodowej w Warszawie (dalej AIPN Warszawa), Akta w sprawie „Zbrodni hitlerowskich w Lubelszczyźnie”, SAL-193/I, k. 54-55.

${ }^{10} \mathrm{~W}$ listopadzie $1941 \mathrm{r}$. Niemcy przeprowadzili na Zamojszczyźnie wysiedlenia sondażowe, zaś masową akcję wysiedleńczo-kolonizacyjną rozpoczęto na tym terenie w nocy 27 XI $1942 \mathrm{r}$. W jej strefie znalazło się ok. 110 tys. Polaków, w tym ok. 30 tys. dzieci, zamieszkujących w 297 wsiach. Wysiedlenia zakończono 15 VIII 1943 r. Z. Mańk ow ski, Między Wisła a Bugiem 1939-1944, Lublin 1978, s. 270; J. W n u k, Tragedia dzieci polskich na Zamojszczyźnie, „Zeszyty Majdanka” 1969, t. 3, s. 212; M. Ka s z, W. Kraw czyk, Gehenna dzieci Zamojszczyzny, Zamość 1987, s. 5.

${ }^{11}$ AIPN Warszawa, Szef Policji Bezpieczeństwa i Służby Bezpieczeństwa, Centrala Przesiedleńcza w Poznaniu, Ekspozytura w Łodzi, GK 69/164, Tätigkeitsbericht der Zweigstelle Zamosc der Umwandererzentralstelle Litzmannstadtüberdieerste Woche der Tätigkeit in Zamosc für die Zeit vom 27.XI. bis 3.XII.1942 (Zamość, 8.XII.1942), k. 16.

121 XII 1942 r., a więc czwartego dnia po rozpoczęciu wysiedleń na Zamojszczyźnie, w obozie przebywało 2600 osób, zaś 7 dni później - już 3600 osób. AIPN Warszawa, Okręgowa Komisja Badania Zbrodni Niemieckich w Lublinie, GK 175/217, A. Skóra, ,,U.W.Z.” w Zamościu (maszynopis, b.m. i b.d.w.), k. 9 .

${ }_{13}$ Byliśmy w transportach. Dzieci Zamojszczyzny, wstęp i oprac. B. Kozaczyńska, Warszawa 2017, s. 7. 
Na wieść o pojawieniu się pociągów z dziećmi z Zamojszczyzny - na wpół żywymi, zmarzniętymi, wygłodzonymi i bez opieki - postawa Polaków była jednakowa. Ludność zareagowała błyskawicznie i z ogromną determinacją. Kto mógł, spieszył na stację kolejową bądź do punktów zbornych, by ratować dzieci. Były wśród nich również niemowlęta ${ }^{14}$. Trudy transportowania w towarowych, nieogrzewanych wagonach były potęgowane przez silne mrozy. W tych krańcowo ciężkich warunkach dzieci docierały do miejsc przeznaczenia w stanie wyczerpania, a nawet agonii. Było to też spowodowane kilkudniowym bądź kilkutygodniowym pobytem $\mathrm{w}$ obozie przejściowym w Zamościu. Od chwili rozpoczęcia wysiedleń, tj. nocy 27 listopada 1942 roku, do początku marca 1943 roku umieszczano w tym obozie wszystkich Polaków wysiedlonych z Zamojszczyzny ${ }^{15}$. Najtragiczniejszy los spotkał dzieci. Dla wielu z nich obozowa brama zamknęła się na zawsze... Ich dramat potęgowało sadystyczne rozbijanie rodzin podczas selekcji rasowej. Przeprowadzano ją w obozie na podstawie oceny wyglądu zewnętrznego osoby „badanej”, opierając się na wzorcu rasy nordyckiej. Zwracano przede wszystkim uwagę jasne włosy, niebieskie oczy i odpowiedni kształt twarzoczaszki. Te dzieci, które nie spełniały kryteriów rasowych, odłączano siłą od rodziców i umieszczano w najgorszych, tak zwanych końskich barakach, pod opieką staruszków, często schorowanych, niedołężnych i wymagających troski. Panujące w obozie skrajne warunki egzystencjalne zbliżone były do tych, w jakich przebywali więźniowie niemieckich obozów koncentracyjnych. Głodowe racje żywnościowe, niehumanitarne warunki higieniczne i sanitarne oraz okrucieństwo załogi obozu w Zamościu prowadziły do szybkiego wyniszczenia fizycznego i psychicznego wysiedleńców. Brak opieki lekarskiej oraz medykamentów dziesiątkowały więźniów. Wysoka śmiertelność panowała w szczególności wśród dzieci ${ }^{16}$.

Po dotarciu transportów do stacji docelowych Niemcy nie interesowali się dalszym losem wysiedleńców. Jedynie żądali, by sporządzić ewidencję tych osób oraz miejsc ich zakwaterowania. To znacznie ułatwiło Polakom organizację akcji pomocowej. Jak się okazało, sprawa utworzenia tak zwanych wsi rentowych nie została jeszcze doprecyzowana (mimo rozpoczęcia wysiedleń), zaś transporty do dystryktu warszawskiego kierowano jako „RD”, czyli z przeznaczeniem do wsi rentowych. Dlatego nie ulega wątpliwości, że dzieci z „transportów śmierci” miały ogromne szanse na przeżycie dzięki natychmiastowej reakcji miejscowej ludności polskiej, jej zaangażowaniu w błyskawicznie podjętą akcję pomocową oraz wielomiesięcznej opiece, jaką je otoczono od chwili przyjazdu.

Priorytetem w organizacji pomocy było umieszczenie najciężej chorych dzieci w szpitalach bądź w tworzonych naprędce prowizorycznych „szpitalikach”. Po otwarciu wagonów okazało się, że stan zdrowia wielu wysiedleńców był katastrofalny

${ }^{14}$ Archiwum Akt Nowych w Warszawie [dalej: AAN], Rada Główna Opiekuńcza. Biuro Centrali w Krakowie 1940-1945 [dalej: RGO w Krakowie], 777, Raport z wyjazdu służbowego do Parysowa w dn. 17-18 grudnia 1942 r., Garwolin, 28 XII 1942 r., k. 26.

${ }_{15}$ Na początku III 1943 r. wysiedlenia na Zamojszczyźnie ustały. Po ich wznowieniu, 23 VI tego roku, wysiedlaną ludność umieszczano w obozach przejściowych w Zamościu i Zwierzyńcu, a następnie wywożono do Lublina (do KL Lublin lub do obozów przejściowych przy ul. Krochmalnej).

${ }^{16}$ H. Kajtel, op. cit., s. 27, 29. 
w efekcie kilkudniowego bądź kilkutygodniowego pobytu „za drutami” w Zamościu. Przykładowo dzieci przyjęte do Szpitala Miejskiego w Siedlcach, jak zeznał jeden z lekarzy udzielających im pomocy, znajdowały się „w opłakanym stanie”: były brudne, zawszone, zaniedbane. Większość z nich chorowała na zapalenie płuc ${ }^{17}$. Inny lekarz siedlecki po przeprowadzeniu wstępnych badań stwierdził u dzieci zapalenie płuc, odmrożenia II i III stopnia, zapalenie stawów i owrzodzenia oraz skrajne wycieńczenie $^{18}$. Podobnie sytuacja zdrowotna dzieci przedstawiała się na terenie pozostałych dwu powiatów, do których dotarły transporty z wysiedleńcami. W niektórych miejscowościach, na przykład w gminie Mrozy (powiat mińsko-mazowiecki) wraz z przyjazdem wysiedleńców z Zamojszczyzny pojawiły się ogniska tyfusu plamistego $^{19}$. Tak więc rozpoczęła się walka o ratowanie ich życia i zdrowia.

Akcja pomocowa przybrała zróżnicowaną formę we wspomnianych powiatach dystryktu warszawskiego, w zależności od miejscowych warunków i możliwości zaspokojenia istniejących potrzeb wysiedleńców. Ciężar pomocy wysiedleńcom spadł na barki miejscowej ludności, a także agend terenowych Rady Głównej Opiekuńczej $(\mathrm{RGO})^{20}$, które zajęły się organizacją i koordynacją pomocy we współpracy z lokalnymi władzami miejskimi i gminnymi. W szczególnie trudnej sytuacji znajdowały się wysiedlone dzieci w powiecie garwolińskim. Wiele miejscowości zniszczono podczas działań wojennych. Brakowało nie tylko lekarstw i środków czystości, ale również bielizny, ciepłej odzieży i obuwia, sienników, koców itp. Wysiedleńców lokowano w miejscowych rodzinach bądź w mieszkaniach pożydowskich (najczęściej wymagających remontu), między innymi w Żelechowie i Parysowie ${ }^{21}$. Podkreślić należy, że do Żelechowa skierowano ponad 900 wysiedleńców z Zamojszczyzny ${ }^{22}$. Mimo to nastrój ludności był przychylny dla przyjezdnych dzieci, więc przede wszystkim zabrano do opiekunów zastępczych dzieci samotne - informował pracownik Polskiego Komitetu Opiekuńczego (Pol.KO) w Garwolinie na kartach jednego ze sprawozdañ ${ }^{23}$.

Tuż po przyjeździe wysiedleńców z Zamojszczyzny do powiatu garwolińskiego władze Pol.KO w Garwolinie zwróciły się (za pośrednictwem agend terenowych RGO i parafii) z apelem, by zgłaszali się ludzie dobrej woli i zabierali do swych rodzin wysiedlone dzieci. Podkreślano przy tym, że $60 \%$ spośród nich nie ma rodziców, a jedynie opiekunów - niedołężnych dziadków lub babcie bądź osoby zupełnie im obce. Proszono również, by składać ofiary na rzecz nowo przybyłych w gotówce

${ }_{17}$ B. Ko za c zyńs k a, Losy dzieci z Zamojszczyzny wysiedlonych do powiatu siedleckiego w latach 1943-1945, Siedlce 2006, s. 54.

18 Ibidem, s. 54-55.

19 AAN, RGO w Krakowie, 787, Lustracja Delegatury gminnej w Mordach z dn. 28 i 29 IV 1943, Mrozy 12 V 1943 r., k. 130.

${ }^{20}$ Były to komitety miejskie - Polskie Komitety Opiekuńcze (Pol.KO) i ich agendy terenowe na wsiach (delegatury gminne).

${ }^{21}$ AAN, RGO w Krakowie, 777, Raport z wyjazdu służbowego do Parysowa w dn. 17-18 XII 1942 r., W. Tomaszewski, Garwolin, 28 XII 1942 r., k. 26. Decydowały się w nich zamieszkać m.in. matki z dziećmi.

22 Ibidem, Raport z wyjazdu służbowego do m. Żelechowa w dn. 14 i 15 I r. b., W. Tomaszewski, Garwolin, 23 I 1943 r., k. 31.

${ }^{23}$ Ibidem. 
i naturaliach ${ }^{24}$. Apel ten, tak jak przypuszczano, nie przeszedł bez echa. W punktach zbornych, do których początkowo kierowano nowo przybyłych wysiedleńców, zawrzało. Przykładowo w Stoczku Łukowskim (pow. garwoliński) tylko w ciągu jednego dnia, tj. 22 grudnia 1942 roku, osoby prywatne przyjęły na utrzymanie około 70 dzieci (spośród 265 wysiedleńców tam skierowanych) ${ }^{25}$. Widok wysiedlonych dzieci przebywających w miejscowym Domu Ludowym na trwałe zapadł w pamięć jednej z mieszkanek pobliskiej wsi Seroczyn, która postanowiła pospieszyć na ratunek sierotom z Zamojszczyzny:

Po przekroczeniu progu dużej sali stanęłam jak wryta. Pod ścianami było trochę rozrzuconej słomy, na której siedziały skulone, stłoczone grupki dzieci patrzące apatycznie przed siebie. Mniejsze płakały, wzywając półgłosem swoje mamy - starsze otulały je, ocierając zapłakane buzie i pocieszając jak tylko umiały ${ }^{26}$.

Nie wszyscy spieszący na ratunek i oferujący pomoc zdołali przyjąć do swych rodzin dziecko (dzieci) z Zamojszczyzny. Wielu z nich dotarło zbyt późno do punktów zbornych (rejestracyjnych). Bywało, że już w ciągu pierwszej doby od chwili przyjazdu transportu dzieci znajdowały swój „drugi dom”, pomoc i życzliwą opiekę w rodzinach zastępczych. Sytuacja taka miała miejsce na przykład w Siedlcach. Kiedy 31 stycznia 1943 roku na siedleckiej stacji kolejowej zatrzymał się „pociąg grozy” wiozący na wpół żywe, zmarznięte, głodne, zalęknione i obdarte dzieci (oraz starców) z Zamojszczyzny, reakcja mieszkańców tego miasta była natychmiastowa ${ }^{27}$. Tłumy siedlczan z żywnością, kocami i ciepłą odzieżą pospieszyły na rampę kolejową, na którą Niemcy polecili kolejarzom odstawić transport ${ }^{28}$. Podczas jego rozładowywania miał miejsce następujący epizod. Po otwarciu wagonów zaczęli wychodzić na wpół zamarznięci, nędznie ubrani wysiedleńcy, którzy w panice pytali, czy pójdą znów „za druty” ${ }^{29}$. Ten przerażający widok skomentował Standartenführer Diel, zwracając się do stojącego w pobliżu dr. Z. Niepokoja:

„Ja wysiedlałem Łotwę, Estonię i Litwę, ale takiego bydła nigdy nie widziałem”. Maszynista kolejowy - wspomina dr Niepokój - widząc to straszne nieszczęście rodaków, krzyknął: „To my wam służymy, a wy co robicie z naszym narodem" i wściekły rzucił szmatę z parowozu pod nogi gestapowca. Diel zwrócił się do mnie z pytaniem: „Co on mówi?”. Starałem się opanować i odpowiedziałem spokojnie: „On jechał całą noc, jest zmęczony i głodny, stąd jego irytacja”. Diel nie odpowiedział nic $^{30}$.

${ }^{24}$ Ibidem, 1050, Sprawozdanie Polskiego Komitetu Opiekuńczego w Garwolinie z przyjazdu w XII br. I, II i III-go transportu wysiedlonych do powiatu garwolińskiego, Garwolin, 21 XII 1942 r., k. 155.

${ }_{25}$ Ibidem, 777, Raport z pobytu służbowego w Stoczku w dniu 22 XII 1942 r., Garwolin, 8 I 1943 r., k. 18.

${ }^{26}$ Dzieci Zamojszczyzny, „Gospodyni” 1986, nr 39, s. 2.

${ }^{27}$ Szerzej na temat akcji pomocowej i losach wysiedlonych dzieci w powiecie siedleckim: B. Kozaczyńska, op. cit., s. 48 i n.

${ }^{28}$ Jedna z kobiet przyniosła ze sobą nawet garnek rosołu. F.J. Górski, Pamiętać o tamtych dzieciach, „Tygodnik Zamojski” 1985, nr 40, s. 8.

${ }^{29}$ B. Kozac zyńs ka, Losy dzieci z Zamojszczyzny..., s. 49.

${ }^{30}$ Centrum Pomnika Dzieci Zamojszczyzny w Siedlcach, Z. Ni i p ok ój, Wspomnienia moje z okresu wysiedlenia Polaków z Zamojszczyzny przez hitlerowców, mps., b.m. i b.d.w. 
W Siedlcach, podobnie jak i w innych miejscowościach docelowych transportów, dalsze losy wysiedleńców z Zamojszczyzny były Niemcom obojętne. Nakazali oni jedynie ich rejestrację w budynku miejscowego Pol.KO, gdzie czekały przygotowane dla nich kwatery. Udawali się tam mieszkańcy miasta z nadzieją wzięcia na wychowanie, ewentualnie pod opiekę, dziecka (dzieci) z Zamojszczyzny. Przynoszono ze sobą żywność (m.in. chleb, masło, wędlinę, ser, smalec itp.), odzież, koce itp., by „[...] wysiedleni mogli jeść, ile chcą, tak długo, jak długo będą mogli tu pozostać" - wspomina Jan Bednarzak, siedlczanin pracujący podczas okupacji niemieckiej w miejscowym Pol.KO ${ }^{31}$.

Trzy dni później, 3 lutego 1943 roku, zorganizowano w Siedlcach pogrzeb wysiedleńców. W zbiorowej mogile pochowano 23 osoby: dzieci i dorosłych, którzy nie wytrzymali trudów transportowania i zmarli bezpośrednio w wagonach (9 osób) bądź w ciągu następnych godzin - po przyjeździe transportu. Jego organizacją zajął się polski burmistrz Siedlec, Stanisław Zdanowski. Niemiecki komisarz miasta wydał zgodę „na cichy pogrzeb”. Pogrzeb przerodził się w milczącą manifestację z udziałem wielotysięcznego thumu ludności polskiej z Siedlec i okolic. Po skróconym ceremoniale pogrzebowym w miejscowym kościele, przy biciu dzwonów, kondukt z 23 trumnami wyruszył ulicami miasta. Mieszkańcy Siedlec i okolic w milczeniu, ze łzami w oczach podążali na pobliski cmentarz. Nie skorzystano z pomocy taboru miejskiego - trumny ze zwłokami wysiedleńców siedlczanie nieśli na własnych ramionach. Liczbę osób uczestniczących w manifestacji obliczyli Niemcy na $3000-4000^{32}$, natomiast na łamach konspiracyjnych pism podawano liczbę 5000 osób (kondukt rozciągnął się na przestrzeni $1 \mathrm{~km}$ ) 33 . W „Relacji warszawskiego urzędu służby bezpieczeństwa o skutkach zamojskiej akcji przesiedleńczej w dystrykcie warszawskim" zapisano:

Trumny przez całe miasto nieśli młodzi Polacy, przy czym tłum zachowywał się stosunkowo spokojnie. W uroczystości kościelnej wzięły udział w zwartych szeregach dzieci szkolne. Reprezentowana była prawie cała polska inteligencja miasta. Wśród niej można było zauważyć także polskich urzędników w służbie niemieckiej ${ }^{34}$.

Nastrój wielkiej powagi i skupienia Polaków zrobił ogromne wrażenie na Niemcach (cywilnych), którzy „,pojedynczo, zawstydzeni i przybici, szli za pogrzebem”35.

Niemcy nie próbowali rozpraszać manifestujących. Ich działania ograniczyły się jedynie do aresztowania osób fotografujących to wydarzenie. Nieco później, w kwietniu 1943 roku, aresztowano i osadzono na Pawiaku burmistrza Siedlec Stanisława

31 J. Bednarzak, O zachowanie w powiecie siedleckim egzystencji dzieci i dorostych (ze wspomnień) [w:] Dzieci i młodzież w latach drugiej wojny światowej, red. C. Pili c ho w s ki, Warszawa 1982, s. 372.

32 Zamojszczyzna - Sonderlaboratorium SS. Zbiór dokumentów polskich i niemieckich z okresu okupacji hitlerowskiej, red. C. Madajczyk, t. I, Warszawa 1979, s. 384 (Relacja warszawskiego urzędu służby bezpieczeństwa o skutkach zamojskiej akcji przesiedleńczej w dystrykcie warszawskim).

33 „Samoobrona” 1943, nr 3, s. 5.

${ }^{34}$ Zamojszczyzna - Sonderlaboratorium SS, s. 384 (Relacja warszawskiego urzędu...).

${ }^{35}$ Manifestacja w Siedlcach, „Głos Polski” 1943, nr 3, s. 5. 
Zdanowskiego. Jednym z powodów był jego udział w organizacji pogrzebu wysiedleńców z Zamojszczyzny ${ }^{36}$.

Wielotysięczny, milczący pochód ulicami Siedlec na miejscowy cmentarz, był groźnym „memento” dla okupanta ${ }^{37}$. Następne pochówki zmarłych wysiedleńców z Zamojszczyzny niemieckie władze okupacyjne miasta nakazały przeprowadzać nocą (wyznaczono w tym celu specjalną ekipę) ${ }^{38}$. Znamienne wydają się słowa J. Bednarzaka odnoszące się do wydarzeń, które miały miejsce w Siedlcach w ciągu pierwszych dni po przyjeździe „transportu śmierci”: „Żywiołowość i siłę reakcji siedleckiego społeczeństwa na widok umęczonych Zamojszczan, pierwsze spontaniczne akty pomocy, rozchwytywanie dzieci, udział w pogrzebie zmarłych można porównać do wybuchu wulkanu, nad którym nic nie zdoła zapanować"39.

Pogrzeb 16 wysiedleńców z Zamojszczyzny w Łosicach (powiat siedlecki), zorganizowany na początku lutego 1943 roku, przerodził się, podobnie jak w Siedlcach, w cichą manifestację miejscowej ludności przeciwko eksterminacyjnej polityce Niemców wobec polskiego narodu, w tym zbrodniom okupanta na polskich dzieciach z Zamojszczyzny. W świetle relacji bezpośredniego uczestnika pogrzebu rano w Losicach zebrało się przed kościołem „całe miasto”: „Nie wiem, jak to się stało, ale Niemcy zezwolili wówczas na publiczny pogrzeb - wspomina Zygmunt Nowaczek. - Ba, żandarmi zniknęli tego dnia z ulic, jakby się bali tych dziecięcych zwłok. [...] Trumny nieśliśmy na ramionach, a za trumnami szło całe miasto. I płacz był straszny wszystkich" ${ }^{\text {"40 }}$. Jak wspomina jedna z mieszkanek Łosic, płacz straszny niósł się nad łosickim Rynkiem po przywiezieniu do tego miasteczka wysiedlonych dzieci: „Widok przybyłych dzieci był tak straszny, że z jednej strony nie było na Rynku człowieka, który by nie płakał, a z drugiej strony wywołał on ogromne wzburzenie wśród Polaków. W tej chwili czuliśmy wszyscy potrzebę walki z okupantem"41.

I w Łosicach nie zabrakło ludzi dobrej woli, którzy pospieszyli na ratunek wysiedlonym dzieciom. W ciągu dwóch dni rozdzielono dzieci z transportu: „Polacy dosłownie je sobie wyrywali. Popyt na dzieci znacznie przewyższał liczbę przybyłych"42. Pierwszym odwiedzającym kwatery był miejscowy proboszcz, który przyjął opiekę duchową nad wysiedlonymi ${ }^{43}$.

O tragedii dzieci z Zamojszczyzny mieszkańcy dowiedzieli się, jak stwierdził Józef Rumik (po wojnie burmistrz Łosic), z konspiracyjnego pisma „Żywia” wydawanego przez Ludowy Związek Kobiet. W styczniowym numerze „Żywii” informowano o prowadzonej przez okupanta akcji wysiedleńczej na Zamojszczyźnie i wywożeniu dzieci oraz pomocy, jakiej udzielano wszędzie tam, gdzie pojawiły się

\footnotetext{
${ }^{36}$ Z. Anu z, Ludzie Siedlec i Podlasia. Prezydent „Szpak”, „Nowe Echo Podlasia” 1995, nr 6, s. 9.

37 J. P a w lak, Nie walczyli dla stawy i krzyży. Ośrodek ZWZ-AK Siedlce „,Sówka” 1939-1944, Warszawa 1996, s. 64.

${ }^{38}$ Ibidem.

39 J. Bednarzak, op. cit., s. 373.

40 S. Ja d c zak, Dzieci Zamojszczyzny w Eosicach (2), „Słowo Podlasia” 1983, nr 10, s. 4.

${ }^{41}$ Idem, Dzieci Zamojszczyzny, „Słowo Podlasia” 1983, nr 9, s. 12.

${ }^{42}$ Zamojszczyzna - Sonderlaboratorium SS, s. 384 (Relacja warszawskiego urzędu...).

${ }^{43}$ Ibidem.
} 
transporty z wysiedlonymi dziećmi, między innymi o spontanicznej reakcji społeczeństwa Warszawy na początku stycznia 1943 roku ${ }^{44}$ W końcowej części artykułu zamieszczono apel:

Wzywamy wszystką ludność mieszkającą przy torach i stacjach kolejowych do baczenia i stwierdzania miejsc, gdzie pojawią się dzieci. W razie wykrycia wagonów, starać się jak najszybciej i najsprawniej dzieci z nich wydobyć. Gdzie się da, wykupić, gdzie się da, wykraść. Zaopiekować się dziećmi natychmiast. Podzielić pomiędzy rodziny. Działać spokojnie, z rozwagą. Ratować dzieci! Ratować dzieci! ${ }^{45}$.

Hasło to szybko dotarło do mieszkańców Łosic i okolicznych wsi. Także i w tej części powiatu siedleckiego ludność nie pozostała obojętna na krzywdę bezbronnych dzieci. Fakty te potwierdzają liczne wspomnienia i relacje osób ratujących i ratowanych. Przykładowo Julia Rodzik z Zamościa (wówczas jedenastoletnia) wspomina o troskliwej opiece i dobroduszności mieszkańców Łosic: „Mieszkańcy miasteczka otoczyli nas troskliwą opieką. Wiedzeni odruchem serca brali do swoich domów wynędzniałe, schorowane dzieci, by zastąpić im rodzinę"46. W rodzinie, w której przebywała ,na wysiedleniu” w Łosicach, miała zapewnione doskonałe warunki bytowe:

Ja zostałam przyjęta za „,órkę” przez państwo Marię i Ludwika Franczuków. Moimi „nowymi braćmi” byli: piętnastoletni Stefan i siedemnastoletni Ryszard. Cały czas traktowali mnie oni serdecznie, z pełnym rycerskim szacunkiem, zaś ich rodzice otoczyli mnie troskliwą opieką i uważali za swoją prawdziwą córkę. [...] znalazłam w ich domu doskonałe warunki bytowe; oni również posłali mnie do szkoły (do klasy piątej); chodzili ze mną do kościoła, zadbali o wszystkie moje potrzeby ${ }^{47}$.

Przyjmując dzieci do swych rodzin, starano się ulżyć ich wysiedleńczej niedoli, otoczyć je opieką i stworzyć namiastkę ,normalności” w tym trudnym dla nich okresie. W wielu rodzinach zastępczych dzieci z Zamojszczyzny traktowano na równi z pozostałymi domownikami. W takiej rodzinie przebywała między innymi Maria Matuszyńska (wówczas jedenastolatka), wysiedlona z Uchań (pow. hrubieszowski). Jej wojenne losy związane są z Siedlcami.

Tam mi włoski obcięli, wykąpali, dali czyste ubrania - wspomina o pobycie w jednej z rodzin. - Przyjęli mnie jako swoje dziecko. Zaraz zapisali mnie do szkoły. Chodziłam razem z ich córką - jednolatką [...]. To byli bardzo dobrzy ludzie. Było mi tam bardzo dobrze. Opiekunka była bardzo dobrą gospodynią, dobrze im się powodziło. Dobrzy ludzie byli. Dzisiaj nikt by tak nie przyjąat8.

${ }^{44}$ Na początku I 1943 r. przez Warszawę przejeżdżały transporty z polskimi dziećmi wysiedlonymi z Zamojszczyzny. Najprawdopodobniej były to dzieci wywożone z Zamojszczyzny na zniemczenie do Rzeszy bądź na zagładę do niemieckich obozów koncentracyjnych. Wiadomo, że w tym czasie Niemcy nie wywozili z obozu przejściowego $\mathrm{w}$ Zamościu polskich dzieci ani do dystryktu warszawskiego, ani też do pozostałych dystryktów w Generalnym Gubernatorstwie. B. Ko zac zy ń s ka, Wstęp [w:] Byliśmy w transportach, s. 7.

${ }^{45}$ Ratować dzieci! Ratować dzieci!, „Żywia”, I 1943, s. 5.

46 J. Rodzik, Mój mały braciszek Krzyś umart z głodu... [w:] Wojenne losy Dzieci Zamojszczyzny, oprac. J. Rodzik, Zamość 2007, s. 93-94.

47 Ibidem.

${ }^{48}$ M. Matuszyń ska, Przyjęli mnie jako swoje dziecko [w:] Byliśmy w transportach, s. 140. 
Na opiekunach ciążyła ogromna odpowiedzialność za dzieci. Opieka nad dzieckiem z transportu wymagała niejednokrotnie poświęcenia, zwłaszcza jeśli było ono ciężko chore. Wysiedlona do Siedlec Janina Zielińska (wówczas pięcioletnie dziecko) wspomina:

Byłam w stanie agonii, szczękościsk, głodowy duży brzuszek, wycieńczenie, odleżyny wygryzione przez wszy, aż do kości [...]. Ofiarność społeczeństwa była ogromna, kto mógł ratował dzieci, a przecież trudno było w czasie okupacji wyżywić nawet swoją rodzinę, a zawszone i chore dziecko trzeba było ogolić, wykąpać, odzież spalić i długo, długo leczyćc ${ }^{49}$.

Stan zdrowia wielu dzieci z ,transportów śmierci” był, jak już sygnalizowano, katastrofalny. Niektóre z nich nawet jeszcze przez kilka miesięcy dochodziły do zdrowia. Jednym $z$ takich dzieci była Jadwiga Piotrowska (wówczas ośmioletnie dziecko), którą Niemcy wywieźli w transporcie do powiatu siedleckiego (razem z mamą i czterema siostrami). $Z$ pobytu na wysiedleniu zapamiętała między innymi zapach świeżo umytej podłogi w szkole w Mordach, w której początkowo ulokowano nowo przybyłych z Zamojszczyzny. Trafiła do rodziny kolejarskiej z podsiedleckiej wsi Stok Lacki.

Rano przyszli nieznani ludzie, ażeby nas zabrać do siebie. [...] Z Mordów do domu cioci jechałyśmy towarowym pociągiem. W drodze ciocia tamowała mi krwotok z nosa, to dziwne, szłam wtedy jeszcze o własnych siłach. Tylko kiedy położyłam się do łóżka, to długo z niego nie wstawałam, prawie trzy miesiące. Pewnego razu ciocia sprowadziła lekarza z Siedlec, ale mnie nie wyleczył. [...] Kiedy mama zobaczyła mnie w chorobie [odwiedziła ją dwukrotnie u opiekunów - B.K.], to prawdopodobnie modliła się, ażebym umarła i nie męczyła się. Tak mówiła mi później sama, pamiętam, że usta to miałam jeden strup, nie mogłam ani zamknąć, ani otworzyć szerzej. Ciocia mnie karmiła, odżywiała jak mogła w tych ciężkich czasach. [...] To ciocia nie tylko mnie pielęgnowała w czasie choroby, ale kiedy wyzdrowiałam, posłała do szkoły ${ }^{50}$.

Przytoczone powyżej fakty jednoznacznie określają pozytywne postawy mieszkańców wsi i miasteczek wschodniej części dystryktu warszawskiego ratujących wysiedlone dzieci z determinacją, zaangażowaniem i poświęceniem. Niewątpliwie był to ogromny zryw społeczeństwa w celu ratowania życia niewinnych i bezbronnych polskich dzieci. Nie oznacza to jednak, że wszyscy Polacy na tym terenie byli życzliwie ustosunkowani do nowo przybyłych wysiedleńców z Zamojszczyzny, w tym również i tych najmłodszych. Mimo że pracownicy agend terenowych RGO przeprowadzali kontrole warunków bytowych podopiecznych z Zamojszczyzny przebywających w rodzinach zastępczych, nie brak przykładów świadczących o złym traktowaniu wysiedlonych dzieci przez ich opiekunów, a nawet członków ich rodzin (np. dzieci opiekunów) - i to na terenie każdego $z$ trzech wspomnianych powiatów. Zdarzało się, że dzieci z Zamojszczyzny były odbierane opiekunom zwłaszcza tam, gdzie nadmiernie obciążano je pracą fizyczną. Zjawisko to było nieuniknione. Nieraz bywało, że dzieci miały swoje codzienne czynności do wykonania. Przede wszystkim

49 J. Zi ielińska, Wspomnienia z dzieciństwa i okresu powojennego. Gdyby mama żyła..., „Biuletyn Informacyjny Stowarzyszenia Dzieci Zamojszczyzny” 1999, nr 3, s. 5.

${ }^{50}$ J. Pi otrow ska, Kiedy przyszli podpalić dom. Dołączam swój głos do głosu matek, „Tygodnik Zamojski" 1981, nr 41, s. 5. 
pomagały w pracach gospodarskich i domowych. O swoich obowiązkach wspomina Weronika Nowaczewska, wysiedlona z Grabowca (pow. zamojski) do Olszewic k. Kałuszyna (pow. miński):

W Kałuszynie byliśmy w szkole i stamtąd nas ludzie rozbierali. Przyszła taka Pani i wzięła mnie do siebie. Byłam kilometr od Kałuszyna, w Olszewicach, u państwa Witowskich. Kiedy mnie przyprowadziła, zrzuciła na podwórku wszystko ze mnie, bo to wszawica, spaliła i doprowadziła mnie do porządku. [...] Tej mojej Pani syn pracował w gminie, przyszedł i mówi: przywieźli z Zamojszczyzny dzieci, trzeba rozebrać. No i matka jego przyszła. I ludzie porozbierali. [...] Tam miałam obowiązek - trzeba było kartofli naobierać, jeszcze nie umiałam, bo tego nie robiłam nigdy, to obierałam tak na okrągło, to gospodyni mówiła, że tak się jabłko obiera. Naczynia umyć, w sobotę podłogi pofroterować. No i krowy pasłam - razem z Bernardką, też wysiedloną. Ona była w sąsiedniej wiosce.

Jeśli wymagała tego sytuacja, dzieci były przenoszone do innych opiekunów lub umieszczane w placówkach opiekuńczych (istniejących bądź nowo tworzonych).

Nawet jeśli dziecko trafiło do rodziny dobrze sytuowanej, nie zawsze miało tam zapewnioną właściwą opiekę. Przekonał się o tym między innymi Wacław Mil (wówczas dwunastolatek), wysiedlony do Siedlec. Pisze on:

Ja zostałem przyjęty do rodziny dobrze sytuowanej, posiadającej zakład kamieniarski przy ul. Cmentarnej w Siedlcach. Od tej rodziny uciekłem, ponieważ była tam za ciężka praca, a w dodatku źle mnie traktowano. Pościel moja była w dzień przetrzymywana w komórce na węglu. Wieczorem musiałem ją sobie przynosić i ścielić posłanie w kuchni na podłodze. Trzeba było nieraz pod tą zmarzniętą pierzyną długo leżeć, aby można było się nieco ogrzać. Bardzo rano musiałem wstawać i wykonywać różne prace ${ }^{51}$.

Nie był to incydentalny przypadek. Ucieczki wysiedlonych dzieci od opiekunów zdarzały się i w innych miejscowościach.

W akcji pomocowej i opiekuńczej na rzecz dzieci z Zamojszczyzny przebywających „na wysiedleniu” we wschodniej części dystryktu warszawskiego wystąpiły niedociągnięcia, a nawet nadużycia. Bywało, że gospodarze uchylali się od przekazywania dla wysiedleńców tak zwanych zsypów i mleka dla dzieci. W Żelechowie (pow. garwoliński) podopieczni skarżyli się do pracownika RGO na miejscowego lekarza, który ociągał się z wykonaniem badań wysiedlonym dzieciom (oczekiwano na lekarza z Warszawy) ${ }^{52}$. W jednym ze sprawozdań informowano o przypadku okradania wysiedleńców zakwaterowanych w willi letniskowej „Świt” w Łaskarzewie przez dozorcę tego budynku ${ }^{53}$. Z biegiem czasu niektórzy opiekunowie rezygnowali z opieki nad wysiedlonym dzieckiem (bądź dziećmi). Było to uzasadnione, o ile

51 AIPN Warszawa, Zamojszczyzna - Wacław Mil, BU 2535/1071, Relacja Wacława Mila z Zamościa, k. 9. Chłopiec postanowił udać się do Miejskiego Zakładu Opiekuńczego w Siedlcach, specjalnie utworzonego dla wysiedleńców z Zamojszczyzny.

52 AAN, RGO w Krakowie, 777, Raport z wyjazdu służbowego do Delegatury w Żelechów miasta w dn. 24 i 25 IX 1943 r., Garwolin, 27 IX 1943 r., k. 376.

53 Dozorca kradł też opał i ziemniaki będące własnością miejscowej delegatury Pol.KO. Ibidem, Raport z wyjazdu służbowego do Delegatury Łaskarzew Osada w dn. 23-24 X 1943 r., Garwolin, 19 XI 1943, k. 430; ibidem, Raport z wyjazdu służbowego do Łaskarzewa w dniu 9 i 11 IX 1943 r., Garwolin, 27 IX 1943 r., k. 383. 
wynikało z lokalnej biedy, spowodowanej przedłużającą się wojną, powodującą wyczerpanie artykułów żywnościowych, odzieży, obuwia itp. Niektórych zmuszała do tego trudna sytuacja materialna, na przykład brak odpowiednich warunków lokalowych.

W maju 1943 roku, a więc po upływie trzech miesięcy od przyjazdu transportu z wysiedleńcami do Siedlec, okazało się, że większość rodzin zastępczych, które zaopiekowały się wysiedlonymi dziećmi, była nieodpowiednia. O fakcie tym informował między innymi doradca RGO na okręg warszawski: „Rodziny te bowiem wzięły dzieci pod wpływem pierwszego zapału w chwili przybycia transportu wysiedlonych, a nie mają warunków do ich utrzymania (złe warunki materialne lub nieumiejętne obchodzenie się z dziećmi, wyzyskiwanie dzieci i obciążanie ich nadmierną pracą" ${ }^{54}$. Zaistniała wówczas potrzeba uruchomienia zakładu opieki całkowitej. Dzięki zaangażowaniu działaczy miejscowego Pol.KO 19 listopada 1943 roku uruchomiono zakład opiekuńczy dla wysiedlonych chłopców („Schronisko dla chłopców") ${ }^{55}$. Siedlecki Pol.KO był uznany za jeden z operatywniejszych Komitetów w staraniach „na własną rękę" o środki rzeczowe na prowadzenie pomocy odzieżowej dla wysiedlonych dzieci. Udawało się na przykład uzyskiwać nieco większe niż minimalne przydziały tak potrzebnej odzieży, bielizny czy obuwia na drewnianej podeszwie, a nawet materiałów, z których szyto odzież we własnym zakresie ${ }^{56}$.

Rezygnacje z opieki nad wysiedlonymi dziećmi zgłaszano - i to dość często w okresie jesienno-zimowym. Jesienią 1943 roku nastąpił wzrost trudności z zapewnieniem opieki zastępczej dzieciom z Zamojszczyzny w powiecie garwolińskim. Jak informował w sprawozdaniu pracownik Pol.KO, dotychczasowi opiekunowie dzieci „,coraz to z różnych względów nie chcą ich trzymać" ${ }^{57}$. W tym czasie przepełniony był sierociniec w Izdebnie (na 24 miejsca przebywało tam 31 dzieci) $)^{58}$. Jedną z przyczyn rezygnacji z opieki nad wysiedlonymi dziećmi były ograniczone możliwości zarobkowania w okresie późnej jesieni i zimy (po zakończeniu robót polowych). Aczkolwiek, jak informowano na kartach sprawozdania RGO, „na ogół jednak pracę znaleźć mogą wszyscy" 59 . Być może dla niektórych opiekunów była to jedynie wymówka, by pozbyć się ciężaru utrzymywania obcego dziecka.

Negatywne zachowania i postawy mieszkańców wschodniej części dystryktu warszawskiego wobec polskich dzieci wysiedlonych z Zamojszczyzny, a także niedociągnięcia $\mathrm{w}$ akcji pomocowej nie podważają tezy o znaczącej pomocy materialnej i duchowej udzielonej wysiedlonym dzieciom. To niezwykle chlubna karta zapisana przez miejscową społeczność w niechlubnym okresie II wojny światowej. Dominowała postawa solidarności społecznej i mobilizacji działań. Na terenie trzech powiatów: garwolińskiego, siedleckiego i mińsko-mazowieckiego nie zabrakło ludzi

${ }^{54}$ Ibidem, 687, Sprawozdanie doradcy RGO na okręg warszawski, k. 2.

${ }_{55}$ B. Kozaczyńska, Losy dzieci z Zamojszczyzny..., s. 98. Jednym z podopiecznych schroniska był wspominany Wacław Mil.

56 B. Kroll, Rada Gtówna Opiekuńcza 1939-1945, Warszawa 1985, s. 154.

${ }^{57}$ AAN, RGO w Krakowie, 777, Sprawozdanie za miesiąc XI 1943 r., Garwolin, 4 XII 1943, k. 455.

${ }^{58}$ Ibidem.

${ }^{59}$ Ibidem. 
dobrej woli, którzy nie zawahali się pospieszyć dzieciom na ratunek. Pomocy tej nie nakazywano. Wynikała ona z potrzeby serca, wrażliwości na cierpienie drugiego człowieka, jak też z wyznawanych zasad moralnych. Polacy dobrowolnie przyjmowali do swych domów dzieci z Zamojszczyzny, nie zważając na istniejące trudności, z jakimi się borykano, zwłaszcza wobec przedłużającej się wojny i terroru niemieckiego. Zdarzało się, że liczba ofert na adoptowanie dzieci przewyższała liczebność transportów. Do akcji ich ratowania włączyli się zarówno znani z nazwisk lekarze, pielęgniarki, harcerki, siostry zakonne, księża, działacze społeczni, pracownicy RGO, jak i bezimienni już dziś mieszkańcy trzech wschodnich powiatów dystryktu warszawskiego. Nie ulega wątpliwości, że bez ich pomocy przyjęcie dzieci z Zamojszczyzny i roztoczenie opieki nad nimi byłoby niemożliwe.

Ofiarność, determinacja, zaangażowanie i poświęcenie w niesieniu pomocy przez miejscową społeczność polską przez wiele okupacyjnych miesięcy (aż do zakończenia wojny) przyczyniły się do uratowania przez mieszkańców wschodniej części dystryktu warszawskiego większości spośród około 3,5 tys. polskich dzieci wysiedlonych z Zamojszczyzny, które okupant niemiecki uznał za „bezwartościowe rasowo”.

\section{BIBLIOGRAFIA}

\section{Źródła}

Centrum Pomnika Dzieci Zamojszczyzny w Siedlcach

Z. Ni e pokój, Wspomnienia moje z okresu wysiedlenia Polaków z Zamojszczyzny przez hitlerowców, mps., b.m. i b.d.w.

Instytut Pamięci Narodowej w Warszawie

Akta w sprawie „Zbrodni hitlerowskich w Lubelszczyźnie”, SAL-193/I; ZamojszczyznaWacław Mil, sygn. BU 2535/1071

Okręgowa Komisja Badania Zbrodni Niemieckich w Lublinie

Szef Policji Bezpieczeństwa i Służby Bezpieczeństwa, Centrala Przesiedleńcza w Poznaniu, Ekspozytura w Łodzi

Archiwum Akt Nowych w Warszawie

Rada Główna Opiekuńcza. Biuro Centrali w Krakowie 1940-1945, sygn. 687, 777, 787, 1050

\section{Opracowania}

B ednarzak J., O zachowanie w powiecie siedleckim egzystencji dzieci i dorostych (ze wspomnień) [w:] Dzieci i młodzież w latach drugiej wojny światowej, red. C. Pilichow ski, Warszawa 1982.

Byliśmy w transportach. Dzieci Zamojszczyzny, wstęp i oprac. B. K o z a c z y ń s k a, Warszawa 2017. Kaj tel H., Hitlerowski obóz przesiedleńczy w Zamościu. UWZ Lager Zamość, Biłgoraj 2003. 
Kasz M., Krawczy k W., Gehenna dzieci Zamojszczyzny, Zamość 1987.

Ki ełb oń J., Migracje ludności w dystrykcie lubelskim w latach 1939-1944, Lublin 1995.

Kiełboń J., Wysiedleńcy z Zamojszczyzny w obozie koncentracyjnym na Majdanku 1943, Lublin 2006.

Kozaczyńska B., Losy dzieci z Zamojszczyzny wysiedlonych do powiatu siedleckiego w latach 1943-1945, Siedlce 2006.

Ko za c zy ń s ka B., Ocalone z transportów Dzieci Zamojszczyzny. Losy dzieci wysiedlonych z Zamojszczyzny do dystryktu warszawskiego 1942-1945 / Saved from the Transports: The Children of Zamojszczyzna Region, Siedlce 2011.

Kroll B., Rada Główna Opiekuńcza 1939-1945, Warszawa 1985.

Kubica H., Zagłada w KL Auschwitz Polaków wysiedlonych z Zamojszczyzny w latach 1942-1943, Oświęcim-Warszawa 2004.

Madajc zyk C., Generalna Gubernia w planach hitlerowskich, Warszawa 1961.

Mańkowski Z., Między Wisłą a Bugiem 1939-1944, Lublin 1978.

Mars załek J., Hitlerowskie ośrodki terroru w Zamościu [w:] Zamość. Z przeszłości twierdzy i miasta, red. A. Koprukowniak, A.A. Witusik, Lublin 1980, s. 347.

Matus zyńska M., Przyjęli mnie jako swoje dziecko [w:] Byliśmy w transportach. Dzieci Zamojszczyzny, wstęp i oprac. B. Kozaczyń ska, Warszawa 2017, s. 140.

Mą ci or-Majka B., Generalny Plan Wschodni, Kraków 2007.

P a w lak J., Nie walczyli dla sławy i krzyży. Ośrodek ZWZ-AK Siedlce „Sówka” 1939-1944, Warszawa 1996.

Rod zi k J., Mój mały braciszek Krzyś umarł z głodu... [w:] Wojenne losy Dzieci Zamojszczyzny, oprac. J. Rodzik, Zamość 2007, s. 93-94.

W nu k J., Losy polskich dzieci w okresie okupacji hitlerowskiej, Warszawa 1980.

Wnuk J., Tragedia dzieci polskich na Zamojszczyźnie, „Zeszyty Majdanka” 1969, t. 3, s. 212.

Zamojszczyzna-Sonderlaboratorium SS. Zbiór dokumentów polskich i niemieckich z okresu okupacji hitlerowskiej, red. C. Madajc zy k, t. I, Warszawa 1979.

Zi eliń s k a J.,Wspomnienia z dzieciństwa i okresu powojennego. Gdyby mama żyła..., „Biuletyn Informacyjny Stowarzyszenia Dzieci Zamojszczyzny” 1999, nr 3, s. 5.

\section{Czasopisma}

„Gospodyni” 1986, nr 39

„Nowe Echo Podlasia” 1995, nr 6

„Słowo Podlasia” 1983, nr 9-10

„Tygodnik Zamojski”1981, nr 41; 1985, nr 40

\section{Pisma konspiracyjne}

„Agencja Informacyjna »Wieś«” 1943, nr 8

„Biuletyn Informacyjny” 1943, nr 10

„Głos Polski” 1943, nr 3

„Samoobrona” 1943, nr 3

„Walka” 1943, nr 11

„Żywia”, I 1943 